\title{
СУЧАСНІ УМОВИ ОРГАНІЗАЦІЇ НАВЧАЛЬНОГО ПРОЦЕСУ В МЕДИЧНОМУ ВУЗІ
}

Г. В. Булак

Львівський нащіональний медичний університет імені Данила Галиџького

\section{CURRENT CIRCUMSTANCES OF THE EDUCATIONAL PROCESS ORGANIZATION IN MEDICAL UNIVERSITY}

\author{
H. V. Bulak
}

\author{
Lviv National Medical University by Danylo Halytsky
}

\begin{abstract}
Реалізація впровадження державних стандартів вищої освіти супроводжується зміною освітньої педагогіки, що передбачають підготовку компетентних, конкурентоспроможних, відповідальних спеціалістів-медиків, здатних самостійно і творчо вирішувати професійні питання, які неможливо виконати без підвищення ролі самостійної роботи студентів у медичному вузі.
\end{abstract}

Implication of national standards of higher education is accompanied by changes in educational pedagogic, which realizes fostering of competent, competitive, responsible medical specialists, capable solely and creatively solve professional tasks, that impossible to attain without increasing use of self education approach in student studies.

Вступ. На сучасному етапі в умовах оновлення суспільства, бурхливих змін та створення Свропейського простору вищої освіти, одним із головних завдань медичного вузу є підготовка кваліфікованих медиків з високим рівнем фахових знань, умінь та навичок. Для проведення кваліфікованих досліджень потрібні фахівці з відповідною підготовкою, тому поліпшення підготовки до професійної діяльності передбачає навчання студентів у розвитку індивідуальних здібностей, вміння самостійного аналізу, відповідальності за прийняття рішення та уміння правильно організовувати самостійну роботу.

Провідна роль у вирішенні цих проблем належить викладачам медичного вузу, професійна праця яких у сучасних соціально-педагогічних реаліях значно ускладнюється, оскільки задаються нові цільові, змістові, методичні параметри. Відповідно, суттєво підвищуються вимоги до викладача як до особистості й професіонала, ставляться завдання щодо сформованості його мотиваційної сфери й цілісних орієнтацій, педагогічного мислення, технологічної культури, медичної взаємодії з клінікою, творчого потенціалу, здатності до постійного самовдосконалення тощо. Ось чому, в сучасних умовах організації навчального процесу, коли до 50 \% навчального часу приділяється на самостійну роботу, завдання вдоско-

() Г. В. Булак налення іiї змісту і методів будуть все більш актуальними.

Основна частина. Процес становлення нової, багатоступеневої системи освіти супроводжується зміною освітньої педагогіки: $з$ традиційно суб'єктивно-об'єктивної на особисто-орієнтовану, що передбачає постійне зростання самостійності спеціалістів, а при навчанні - значимості самостійної роботи студентів (СРС).

Але, як видно зі спостережень навчального процесу у вищих медичних вузах, ефективні, науково обгрунтовані методи самостійної роботи не зайняли належного місця у навчанні студента. Основний недолік в організації самостійної роботи студентів однотипність форм і видів іï̈ проведення. Відтак, самостійна робота студентів протікає в традиційних формах: реферат, кваліфікаційна робота, а для студентів наукового гуртка - підготовка доповідей на студентських конференціях.

На сьогодні самостійна робота студентів $є$ основою багатоступінчастої вищої освіти. Так, якщо раніше студент відводив самостійним завданням лише додаткову (другорядну) роль, то тепер СРС стоїть нарівні з такими видами навчальних занять, як лекції, практичні заняття, тобто вони рівноправні, рівнозначні, однаково важливі компоненти навчального процесу.

В сучасних умовах самостійна робота - основний вид діяльності студента, який обов'язково повинен 
мати в процесі навчання у вузі дослідницький характер. Так, проведення самостійної роботи у клінічних відділеннях біля ліжка хворого надають змогу студенту уточнити діагноз, призначити додаткові методи обстеження та лікування, які допоможуть виявленню соматичної патології у пацієнта, а викладачу надають можливість оцінити вміння студента самостійно аналізувати, логічно мислити щодо даного захворювання.

Традиційно при вивченні самостійної роботи студента використовується лише робота з літературою, яку викладач рекомендує на практичних заняттях, а зараз сучасні освітні технології дають можливість широко застосувати нові інформаційні технології, в першу чергу комп'ютерні, що $є$ різновидом інтенсивної форми навчання і знаходить все більш широке використання та застосування у підготовці студента.

Реалізація особисто-орієнтованого підходу, що регламентує вимоги освітньо-професійних програм, приводить до змін у позиції викладача. Роль викладача залишається такою ж важливою, як і раніше, але змінюються основні функції: він тепер не $є$ джерелом первинної змістовної інформації, а лише організовує пізнавальну діяльність студентів, консультує і здійснює систематичний контроль аудиторної самостійної роботи студентів, орієнтуючи їх на різноманітні види самостійної діяльності, на пріоритет діяльності дослідницького, творчого характеру.

\section{Література}

1. Власова О. І. Педагогічна психологія : навчальний посібник / О. І. Власова. -К. : Либідь, 2005.-400 с.

2. Вознюк Н. М. Етико-педагогічні основи формування особистості : навчальний посібник / Н. М. Вознюк. К. : Центр навч. літератури, 2005. - 196 с.

3. Зазюн I. А. Педагогічна майстерність / I. А. Зазюн. К. : Вища школа, 1997.-349 с.

4. Наука та освіта - 2006 : матеріали IX Міжнародної науково-практичної конференції. - Дніпропетровськ, 2006. - Т. 3: Педагогічні науки. -108 с.

5. Семенова А. В. Основи психології і педагогіки : навчальний посібник / А. В. Семенова, Р. С. Гурін, Т. Ю. Осипова. -К. : Знання, 2006. -319 с.

6. Степанов О. М. Основи психології і педагогіки : навчальний посібник / О. М. Степанов, М. М. Фіцула. К. : Академвидав, 2005.-520 с.
Ефективність самостійної роботи студентів значною мірою залежить від організаціїіїі контролюз боку викладача. Мета контролю самостійної роботи студентів - допомогти студенту методично правильно з мінімальними затратами часу засвоїти теоретичний матеріал і придбати навички практичного професіоналізму у вирішенні певного виду завдань 3 навчальної тематики. Форми контролю, як правило, залежать від конкретної навчальної теми, від ії змісту, об'єму годин (кредитів) на ії̈ вивчення, виду завдань для самостійної роботи студентів, від досвіду викладача тощо.

Таким чином, реалізація впровадження державних стандартів вищої освіти, які регламентують вимоги до освітньо-кваліфікованих характеристик, освітньопрофесійних програм та способів педагогічної діагностики при підготовці спеціалістів 3 вищою медичною освітою передбачають підготовку компетентних конкурентоспроможних, відповідальних спеціалістів-медиків, здатних самостійно і творчо вирішувати професійні питання, які неможливо виконати без підвищення ролі самостійної роботи студентів у вузі.

Висновок. Індивідуальна освітньо-професійна програма формується з участю студента та допомоги викладача, що дозволяє не тільки без проблем засвоїти матеріал та удосконалити практичні навички, але й набути навиків професіоналізму.

7. Сорочинська В. С. Організація роботи соціального педагога : навчальний посібник / В. С. Сорочинсъка. К. : Кондор, 2005.- 198 с.

8. Соціальна педагогіка: мала енциклопедія / за заг. ред. проф. І. Д. Звєрєвої. - К. : Центр навчальної літератури, 2008. $-336 \mathrm{c}$.

9. Філоненко М. М. Психологія спілкування. Підручник / М. М. Філоненко. - К. : Центр учбової літератури, 2008. -224 c.

10. Шевців 3. М. Розробка та впровадження соціальнопедагогічних проектів / В. М. Шевців. - Рівне : РДГУ, 2010. $-114 \mathrm{c}$. 